\title{
INTERROGATION OF DETAINEES DURING AN ATTEMPT TO ILLEGALLY CROSS THE STATE BORDER IN 1938 - A SOURCE OF INTELLIGENCE INFORMATION
}

\begin{abstract}
The hereby article presents events that took place on the territory of Carpathian Ruthenia in 1938/1939 in the context of information obtained by the Border Guard during the interrogation of detained people attempting to cross the border illegally. The article is based on the critical examination method of source materials which are stored in the National Historical Archives in Lviv. The temporal caesura are the documents created by the Border Guard officers between October and December 1938. The article consists of two parts: the introduction, where the author discusses the situation of Carpathian Ruthenia at that time and the main part, which presents passages from arrests protocols of the volunteers for Carpathian Sich. The presented article is supplemented by author's proper comments. By presenting the above mentioned subject, the author points out the danger posed by a tiny Carpatho-Ukraine state for the internal security of Poland.

The author stresses out the role of Ukrainian organizations in Poland. The analysis of the content of testimonies of detained people (in the preserved records of interrogation) indicates a huge commitment of Ukrainian communities in the idea of creating Ukrainian state and a good organization of transportation across the border of Ukrainian volunteers from Poland to Ukrainian armed forces being formed in the territory of Chust.

Furthermore, the article covers information about the cooperation concerning counterintelligence protection of the borderline between the Border Guard and Independent Information Departments.
\end{abstract}

Keywords: Border Guard, illegal border crossing, borderland, record of interview, interview, source of information, Czechoslovakian army deserters, Carpathian Ruthenia, Volunteers for Carpathian Sich,

At the end of the thirties of the twentieth century in the Second Polish Republic the process of illegal border crossing increased, especially in its south-eastern section (about $180 \mathrm{~km}$ ) running in the Carpathian area adjacent directly to the area of Carpathian Ruthenia. The factor generating this phenomenon was the Carpatho-Ukraine state and its armed forces Carpathian $\mathrm{Sich}^{2}$ formed in the decaying Czechoslovakia, as well as the mass desertion of

${ }^{1}$ Piotr Kozłowski (mjr rez. SG), PhD, The State Higher School of Technology and Economics in Jarosław. ORCID: 0000-0002-9248-0560

2 Carpathian Sich - Carpathian Sich National Defense Organization formed on the $9^{\text {th }}$ of November 1938. Initially, it had about 2 thousand fighters at the end of their existence in March 1939 about 6 thousand soldiers. Many Polish citizens served in this formation. At the moment it is difficult to 
German native soldiers from of Czechoslovak armed forces. The events which at that time took place in the Carpathian Ruthenia ${ }^{3}$ were closely watched by the citizens of the eastern voivodships of the Second Polish Republic. The situation that emerged at the end of 1938 in the Carpathian Ruthenia gave hope in the future for improving the fate of the Ukrainian people in Poland, especially since the Carpathian Ruthenia in pre-war Czechoslovakia was mostly inhabited by Ruthenians ${ }^{4}$.

During this period, Ukrainian factors in Poland have recognized that after years of waiting for, an opportunity arises to create an independent state in the Carpathian Ruthenia territory, which in the future will become the nucleus of The Great Ukraine. An extremely accurate and graphical reference to the situation that prevailed at the turn of 1938/1939 in the Carpathian Ruthenia was the title of the book by Michał Jarnecki and Piotr Kołakowski referring to the Carpathian Ruthenia - "Ukrainian Piemont".

In the initial period, the forming Ukrainian state was too weak and required external support. The same referred to the Ukrainian armed forces being formed in Carpathian Ruthenia, which without a "Polish contingent" would have great difficulty in forming 5 .

This Main Leader of the Organization of Ukrainian Nationalists ${ }^{6}$ (OUN), decided to use this situation, especially as the idea of building an independent Ukrainian state became

determine the exact number of Polish volunteers in the formation. Dariusz Dąbrowski, referring to the materials of the Second Division of General Staff of the Polish Army, believes that from October 1938 until the break-up of the formation by the Hungarian army in March 1939 approximately 2 thousand Polish citizens of Ukrainian nationality escaped from Poland to the Carpathianregion. However, when referring to the intelligence material of the Border Protection Corps, he states that these services had records of more than 600 people who served in Carpathian Sich and returned to Poland (Dąbrowski, 2007).

3 During Interwar period, the Carpathian Ruthenia / Zakarpattia was the most eastern region of prewar Czechoslovakia, which was wedged between Poland, Romania and Hungary, and border with Slovakia in the west. The country covered an area of about 126 thousand $\mathrm{km}^{2}$, was inhabited mostly by Ruthenians. In administrative terms, Carpathian Ruthenia/Zakarpattia was divided into 4 districts: Użhorod, Huszt Berechowo and Mukaczewo. The capital of the region was a small twentythousand-strong city of Uzhhorod located on the Uzh River near the border with Slovakia. Before the First World War, the area of Carpathian Ruthenia was a part of the Austro-Hungarian Monarchy (Wielka ilustrowana encyklopedia powszechna, 1932).

4 According to Czechoslovak statistics, in 1932, the population of Carpathian Ruthenia (Ruś Podkarpacka) was inhabited by approximately 775,000 people, of which $62.2 \%$ were Ruthenians (451 thousand), approx. 16\% of Hungarians (115 thousand), 13.1 Jews (95 thousand), 2.5\% Czechs (18.7 thousand), $2.1 \%$ Slovaks $(15,900)$ (Wiśniewski, 2007).

${ }^{5}$ In the second half of 1938, the mobilization possibilities of Carpathian Ruthenia were limited. As a result of the Vienna arbitration, which took place on the $2^{\text {nd }}$ of November 1938, a significant part of the Carpathian Ruthenia territory inhabited by the Ruthenians and was handed over to Hungary. In addition, the next negative factor affecting the creation of the Ukrainian Armed Forces was the fact that as a result of the general mobilization announced and carried out in Czechoslovakia in the second half of 1938, the men of Carpathian Ruthenia in recruitment age were still in Czechoslovak military units in the Czech and Slovakia at that time.

${ }^{6}$ Organization of Ukrainian Nationalists / OUN / was founded during the Ukrainian Congress in January 1929 in Vienna. The area of the organization's activity was the area inhabited by Ukrainians in Poland, Romania and the USSR. The main goal of the OUN was to build an independent Ukrainian state. In the Interwar Period, the organization was responsible for a series of terrorist actions against the power apparatus in Poland as well as ordinary citizens, including the assassination in 
popular among Ukrainians living in the territory of the then Polish Repubic. The emerging Ukrainian armed forces, with the silent consent of the Czechoslovak authorities, provided the opportunity for combat training for the activists of the Ukrainian movement from Poland, the more so, as the arrivals to the Carpathian Sich were mostly the Ukrainian youth from Poland. Initially, in an organized recruitment and transfer of volunteers, the OUN used the old routes of courier transfer across the border in the Carpathian region. However, it soon turned out that the existing base of the transfer was insufficient and was not able to ensure efficient organization of the transfer of hundreds of volunteers from Poland. During this period, a dangerous situation was created on the Polish-Czechoslovak border, which had a significant impact on the state security, because young people from eastern Poland started to come to the borderland seeking access to people who would facilitate their transfer to Hust in Carpathian Ruthenia. The people of the borderland were also involved in helping the Ukrainian volunteers. In addition to the existing transfer channels and people involved in the transfer across the border recognized by the Border Guard (hereinafter BG) intelligence unit, new people appeared on the Polish-Czechoslovak border who were involved in Ukrainian activities as well as new transfer routes. This situation had a negative impact on the level of internal security of the state and projected on the state border security system and required an accurate recognition by the Border Guard intelligence unit.

One of the most valuable sources of information on this subject was the possibility of obtaining those information from people detained by BG patrols during illegal crossing of the border or during those attempts ${ }^{7}$. While conducting procedural activities, officers of the Border Guard, during the interrogation of the detainee, had the opportunity to obtain relevant information in the field of political intelligence as well as military intelligence. It should be highlighted here that the pre-war staff of BG had appropriate qualifications in this area. During numerous training in investigative technics which took place in the second half of the thirties of the 20th century, in the BG mother units, as well as during the refresher courses at the Central School of Border Guards in Rawa Ruska, officers and border guards were taught, technics of conducting interrogation of persons detained by BG units among other tactics. According to the guidelines of the anti-trafficking intelligence unit developed for the CSBG students in Rawa, the investigator had to

consider in what direction it (investigation) should be led, what should be determined to demonstrate to the court that such act or other provision of the Act was violated. Only then we can expect success in the course of the case, because the

August 19, 1931 of the well-known pre-war politician of the Polish-Ukrainian cooperation - Tadeusz Hołówka and on June 15, 1934, the Minister of Internal Affairs, Bolesław Pieracki.

${ }^{7}$ In the interwar period according to the provisions of art. 2 of the Ordinance of the President of the Republic of 27 December 1927 on the state borders "crossing the state border was allowed only on the basis of appropriate documents and only on customs routes or in designated by the Ministry of Interior in agreement with the Ministry of Treasury, and regarding airlines also with The Ministry of Military Affairs or the authorities authorized to do so by the above-mentioned ministers - transition points". Therefore, the act of illegally crossing of the border outside the designated points in accordance with the provisions of ar 23 above the ordinance was treated as an offense prone to imprisonment for up to one year or a fine of PLN 300 to PLN 10,000. 
authorities deciding, having evidence of violation of the statutory order, or prohibition must issue a sentence or a conviction... 8 .

The analysis of the preserved interrogation protocols indicates that they provided a lot of valuable information, because people detained by the Border Guard for illegal crossing of the border of the state, being aware of criminal responsibility for the committed, decided on informal cooperation with the officers of BG conducting investigation.

While conducting intelligence activities on the border, the Border Guard information service at the end of 1938 closely cooperated in combating the Ukrainian movement, especially during the mobilization of Ukrainian communities in Eastern Galicia, with Second Division of General Staff of the Polish Army. The result of this cooperation was the exchange of information between the services. In connection with the above, on October 30, 1938, the command of the Eastern and Małopolska Border Guard District Office in Lviv received message from the Chief of Staff of the Corps District Command headquarters (hereinafter CDC) (IV) in Lviv Colonel Rudka, in which the principles of cooperation between the Border Guard and Independent Information Office (hereinafter IIO) which operated in the area subordinated to the Małopolska Border Guard in the field of identifying and combating the illegal Ukrainian movement were defined. According to the guidelines, the area of the Polish borderland directly adjacent to the border with the Carpathian Ruthenia was divided territorially between three defensive intelligence units of the Second Division of the General Staff of the Polish Army, ie:

- Officer's Station of the Independent Information Office of CDC No. VI in Stryj,

- Officer's Station of the Independent Information Office of CDC No. VI in Stanisławów,

- Officer's Station of the Information Office of CDC No. X in Sambor to which the intelligence materials acquired by the Border Guard from the conducted border surveillance and persons detained during the illegal crossing of the border were directed. In the event of the arrest of Polish citizens of the Ukrainian nationality attempting to illegally cross the state border to the forming in Hust Carpathian Sich, the Border Guard authorities were instructed to subject such persons to a detailed interrogation ${ }^{9}$, in order to determine all circumstances related to the recruitment of volunteers, how to organize their transfer across the border, personal data of persons involved in this procedure and information on existing transfer channels. In the case of obtaining information relevant to military counterintelligence during the interrogation of the perpetrator, copies of the reports along with the detainee were sent to the territorially competent IIO officers. These institutions made selection and verification of intelligence information obtained during interrogation performed by both the State Police and the Border Guard. In order to coordinate the work of Intelligence units and facilitate the execution of procedural acts such as the interrogation of a detainee for investigators, a special template - a questionnaire with questions - was prepared in the

\footnotetext{
8 "Guidelines for anti-trafficking intelligence service", developed in 1935 by the lecturer of the Central School of Border Guards, sub-commissioner K. Wróblewski (Archives of the Border Guard in Szczecin, Team of Acts of the Headquarters of the SG (BG), ref. No. 187/154).

${ }^{9}$ Guidelines on dealing with Ukrainians attempting to cross the border illegally No. L.dz. 236 / Inf. Nat. T. O./38 of October 30, 1938, Colonel Rudka, Chief of Staff of the Corps District No. VI in Lviv (Act Files of the Małopolska District Inspectorate of the Border Guard, CDIA in Lviv, ref. No. 204/1/1237).
} 
Independent Information Office of the CDC VI in Lviv. This questionnaire contained 12 specific questions:

1. For what purpose did he come to the borderland/ if for help - then on what basis he supposed that he would find it borderland?

2. By what ways did he come? / where and with who did he stay/

3. Does he have a weapon, if so what?

4. Did he get any help on the road, if so - from whom?

5. Did he intend to cross the border, if so - why did he want to do it illegally?

6. Did anyone should help him on the borde0r

7. By what routes did he intend to cross the border / exactly locality and possibly people with whom he stayed?

8. Does he know about organizing Ukrainian formations abroad and what does he know?

9. Where did he intend to go / what final place /, what road, who was to report to, whether it had a password / this point concerns intentions of crossing the border?

10. Did he intend to join these organizations?

11. Did anyone encourage him to join any Ukrainian formations abroad, or did he read any appeals calling for joining the Ukrainian legion, or was he reading or lecturing about the legion and who was giving it?

12. Is he a member of the CNS or what he knows about this organization? ${ }^{10}$

A separate issue at that time were the deserters from the Czechoslovak army. The fall of morale in the Czechoslovak army that took place in the second half of 1938, and the fear that soldiers of German descent would be caught up in fighting with Hungarians in the Carpathian Ruthenia and in Slovakia contributed to the fact that the soldiers deserted the army at any possible occasion. Then on foot they walked across the Polish-Czechoslovak border to get to Poland ${ }^{11}$. During this period, ie at the turn of 1938/1939, it happened that while performing their official duties, border guards in Malopolska sometimes stopped communist couriers crossing the border. The events that took place in this period in Czechoslovakia, as well as in Europe, contributed to the fact that the protection of the state border in the Carpathian region by the Border Guard ceased to be effective. In connection with the above, in order to strengthen the protection of the state border and to improve the security

${ }^{10}$ Annex to the guidelines of Colonel Rudka, Chief of Staff of the Corps District No. VI in Lviv on the handling of Ukrainians attempting to cross the border illegally (The files of the Małopolska District Inspectorate of the Border Guard, CDIA in Lviv, ref. No. 204/1/1237).

${ }^{11}$ Having the opportunity to get acquainted with the preserved source materials found in the State Historical Archive in Lviv in the case of German deserters from the Czechoslovak army in the second half of 1938, one can assume that the Germans' transfer action across the Polish-Czechoslovak border was organized by the German secret services at a quiet cooperation with Polish military intelligence. This thesis can be provided by the cryptograms sent from the BG Office in Stryj to the command of the East-Małopolska District of the Border Guard in Lviv informing about the number of deserters crossing the Polish state border and sending them to German diplomatic missions in Poland. The file contains also a letter dated October 20, 1938, sent from the District Office in Lviv to subordinate border units, informing that the transfer of Czech-Germans was suspended on 29 September 1938 due to the lack of passports for refugees at German consulates. In connection with the above, the order was issued "preventing the border crossing by Czechoslovak refugees of German nationality..." (The files of the Małopolska Provincial District Inspectorate, CDIA in Lviv, ref. act 204/1/1212). 
situation in the border zone in October 1938, the specially created Branch of the Border Protection Corps (hereafter BPC) "Lviv" was directed to the Polish-Czechoslovak border.

The management of the Border Guard Information Service decided to use an appearance of the deserters and refugees from the Czechoslovak army on the Polish border, at the end of 1938, as another opportunity to obtain intelligence information from Czechoslovakia. To do this, a form has been sent to the Border Units with a list of questions that should be asked by the person conducting the interview of a person apprehended by the Border Services. This form has been divided into three main parts. The first part "general information" included questions to determinate the identity of a detained person, as well as other questions related to state administration, political and national relations, industrial facilities, communications and transport infrastructure. In this part there were also questions whose aim was to obtain information on possible connections of detained with civilians and soldiers living in Poland or abroad. The second part concerned military matters. In this part, the interrogator was to extract from the detainee as much information as possible about military intercourse, on the subject of the detainee's attitude to military service, the service, mobilization assignments, exercises in the reserve and knowledge of garrisons and barracks, as well as Czechoslovak intelligence military. In the second part, there were also questions regarding information about the Czechoslovak state border protection system, which were of particular interest to the BG Information Service, i.e. related to deployment of guards and stations [FS Czechosłowacka ${ }^{12}$ ], the strengthening of border staff, changes in dislocation of border troops, as well as regarding border police and criminal police ${ }^{13}$. The third part of the questionnaire was devoted to the issue of the presence of Soviet Special Services in Czechoslovakia. In this part, by asking the following questions, they tried to determine:

- whether the presence of emissaries of the USSR was observed; if so, in what capacity, where, when and with whom;

- the scope of their operation, the attitude of state authorities to them, the attitude of locals;

- in what direction their activity / military, intelligence, political, economic / is manifested;

- What are the ways in which Soviet expansion into C.S.R., as well as seek to determine whether or not the equipment, ammunition and supplies are arriving on Czech territory ${ }^{14}$.

12 Finančna Stráž Československá - Czechoslovak border service established in October 1918 to protect state borders with a length of $4120 \mathrm{~km}$. Formation was subordinate to the Ministry of Finance, the organizational structure was composed of 5 national directorates separate for the Czech Republic, Moravia, Silesia, Slovakia and Subcarpathian Rus, which were subordinate to inspectorates and border posts. About 29,000 officers served in the formation. In 1938, after the fall of the Czechoslovak Republic on the basis of the Slovak National Directorate of FC in independent Slovakia, the Finančni Stráž of the Slovak Republic was established (Beneš, 2005).

13 Attachment to the detention report of Jan Plakerner, a deserter from the Czechoslovak army, who on November 1, 1938 made an illegal crossing of the state border from Czechoslovakia to Poland (Act files of the Małopolska District Inspectorate of the Border Guard, CDIA in Lviv, ref. akt nr 204/1/1243).

${ }^{14}$ Report on the interrogation of ob. Czechoslovakia by Franciszek Cepcauiera born On December 1, 1907, a German deserter from the Czechoslovak army detained on 25 September 1938 during an attempt to illegally cross the state border from Czechoslovakia to Poland (Act of the Małopolska District Inspectorate, CDIA in Lviv, file no. No. 204/1/1212). 
Detained persons during the attempt to cross the border were interrogated at the headquarters of the Border Guard and Border Guard stations. In the event that the detainee had any interesting information for the investigation, the officer from the Intelligence Unit, territorially competent, ie Stryj, Sambor or Stanisławów ${ }^{15}$, participated in the interrogation of the detainee. The information obtained during the interrogation about Polish volunteers fighting in the Carpathian Sich enabled the BPC and Border Guard to prepare personal lists of people fighting in Carpathian Ruthenia, which were transferred to territorial authorities in Poland. The personal data of the "Polish volunteers" fighting in the Carpathian Sich were received from the border services and used by the Polish territorial authorities to apply for the withdrawal of Polish citizenship from the person included in the aforementioned list ${ }^{16}$.

\section{INFORMATION OBTAINED DURING THE INTERROGATION OF PERSONS DETAINED FOR ILLEGAL CROSSING OF THE POLISH-CZECHOSLOVAK BORDER}

In the collections of the State Historical Archive in Lviv, remain an incomplete files of cases carried by the East-Malopolska Border Guard. About 50 interview protocols, of people detained for attempting to cross the Polish-Czechoslovak state border illegally with intention of entering the Carpathian Ruthenia or returning to Poland have survived. The query of these documents allows you to get acquainted with the situation that prevailed in this period on the borderland in the area adjacent to the Carpathian Ruthenia. The analysis of reports made at that time shows that despite the efforts made by the Border Guard to tighten the state border, this practice has intensified. TheBSG intelligence materials show that the recruitment and transfer of volunteers was a well-organized action based on the borderland population led by the OUN. That is why the border guards from Małopolska with little staff were unable to effectively protect the state border during this period. Considering the fact that in the second half of 1938, around 2 thousand of people fled across the Polish border into the Carpathian Ruthenia, there is a temptation to say that the protection of the PolishCzechoslovak border in this region has become a fiction.

The scale of the problem may be proved by the fact that in the second half of 1937 , guards from the East-Małopolska District Inspectorate of the Border Guard in Lviv detained $201{ }^{17}$ people for attempting to cross the border illegally, and in the corresponding period of 1938, with almost unchanged staff, they detained more than 500 people, which is an increase of over $150 \%$ in the number of people detained in relation to the previous period.

\footnotetext{
${ }^{15}$ In the interrogation of detained deserters by the Border Guard during the attempt to illegally cross the border from branch II of the Main Staff, the head of the IIO Center in Stryj took part - Capt. Leon Szuchtowicz.

16 According to the provisions of art. 11 para. 2 of the Act of 20 January 1920 on the citizenship of the Polish State stating that "the loss of Polish citizenship takes place in the event of a public office or military service in a foreign state without the consent of the Polish Government..." (Journal of Laws of 1920 No. 7 item 44) district poviats have ruled on the loss of citizenship by Polish volunteers who joined the Carpathian Sich. The names of persons deprived of Polish citizenship were sent to the competent voivodes and published in the Polish Monitor. The team of files of the Provincial Office in Lviv, the socio-political department, the District Archives in Lviv, son. act No. $1 / 51 / 2734$.

${ }^{17}$ Reports on the protection of the state border for 1937, the Assembly of the Act of the Border Guard Headquarters, the Archive of New Files in Warsaw, reference number No. 37.
} 
The events that took place on the borderland also contributed to the fact that border guards performed by border guards became hard and extremely dangerous during this period. In carrying out tasks in the field of protection of the state border, conducting the diagnosis of Ukrainian environments, the Polish Border Guard became the object of attacks from the Ukrainian side ${ }^{18}$.

In the second half of 1938, Commissioner Bolesław Mościcki was involved in the transfer of Polish citizens of the Ukrainian nationality to Czechoslovakia on the section subordinate to the SG commissariat in Worocht ${ }^{19}$. The conducted intelligence activities as well as information obtained during the interrogation of people detained during the attempt of illegal crossing of Polish border, allowed to establish the rules of recruitment of volunteers in Poland to Carpathian Sich and to detect a new transfer channel on the border.

On November 27, 1938, the Border Guard patrol stopped Polish citizen of the Ukrainian nationality, Jurko Sołowczuk, son of Matija, born on March 11, 1914, during the attempt of illegal crossing of the border into Czechoslovakia, in Mikuliczyn, Nadwórna county. During the interrogation, which took place in the office of the Worocht BG station, detained Jurko Sołowczuk testified that he was persuaded to cross the border with the intention of joining the Carpathian Sich in the reading club of Proświta ${ }^{20}$ in Mikuliczyń,

where Bilejowicz Ivan, son of Fedor living in Mikuliczyn, last week he read the papers, persuading all members of the Proświta reading club to go to Subcarpathian Ruthenia in order to join the Sich Schooters squad. Later in the hearing, the above mentioned testified that "after crossing the border he would go to Jesiny [a town in Czechoslovakia] and report to Klempuszów ${ }^{21}$, with which he was to ask about Weredziak Iwan, who had to vouch for the admission to the Sich units. Weredziuk Iwan

${ }^{18}$ In the second half of 1938, on the southern part of the border with Carpathian Ruthenia region, there were several attacks on border guards and as well as on the BG objects: On August 19 of 1938, a private apartment of the guard Rajmund Rzepkowski was attacked - the perpetrator broke windows in his apartment and fired two shots, on November 23 of 1938, the building of I Line Branch Jelenkowate was strafed by 6 unknown perpetrators. On December 14, 1938, during patrolling duty, border guard Feliks Majchrzak, from i Line Branch Wyszków, was killed by unknown perpetrators,

19 Worocht Commissariat - a territorial unit of the Border Guard directly subordinate to the Border Guard Inspectorate in Stryj. The BG Worocht Commissariat was responsible for the protection of the state border of $51.47 \mathrm{~km}$ in the Carpathian region. The area of border guards from the Worocht Commissariat was the border area of the Nadwórna poviat. Border guard tasks were carried out by guards from the I Line Branch in Polanica, Howerla, Jabłonica and Woronience, as well as from the II Line Branch in Worocht and from the intelligence posts in Jabłonica and Tatarowo (Kozłowski, 2015).

${ }^{20}$ Proświta - a Ukrainian social and educational organization that operated in the interwar period in the territory of the Second Polish Republic, was founded in 1868 in Lviv on the initiative of Ukrainian activists. In the interwar period, especially after 1928, the Ukrainian Military Organization possessed significant influence in this institution. At that time, Proświta was legibly a place where the Ukrainian national movement was supported by the local Ukrainian intelligentsia. In the late 1930s, Proświta became the base of the Organization of Ukrainian Nationalists (Kulińska, 2009).

${ }^{21}$ Probably the brothers: Vasil, Ivan and Dymitr Klempusz from Jasin, who in the interwar period actively acted for the independence of Carpathian Ukraine. Dymitr Klempusz was a co-organizer of the Hutsul Republic in 1919, in the years 1920-1930 he was the president of the Sich sports 
son of Vasyl from Mikuliczyn, after recruiting 11 colleagues from Zarzecze and Delatyn, went [illegally crossed the border to Czechoslovakia] on November 21, 1938, the way through Chostek to Jasin ...". In addition, the detainee informed the investigator that: "Bernyk Włodzimierz, director and singing teacher in the Poroświty reading club, Więckowski Franciszek, Zbichlej Michał are very hostile towards the Polish State and expect to establish an Ukraine in the Easter - Małoposka region. Members of the active reading club of Proświta in Mikuliczyn are characterized by the fact that they are brought up in the spirit of national-nationalist... ${ }^{22}$.

Initial interrogations of detainees allowed to determine that a special role in the recruitment of volunteers in the Mikuliczyn area as well as in the transfer of people across the border was played by the members of Proświta reading club located in Mikuliczyn, Iwan Bilejowicz and Iwan Weredziak from Mikuliczyn. Those materials showed that Proświta's reading club in Mikuliczyn played a significant role of as a contact point and a place of agitation for Ukrainian youth. Due to the obtained information, the reading club Proświta in Mikuliczyna and its members were taken under observation. Also base on the intelligence recognition of the border, places located directly on the border line, which created appropriate conditions for the transfer of people across the state border were selected for an observation operation. One of such a places was the Bohyński gorge in the Polanica region. Soon, thanks to the efforts of the Border Guard in this area, one of the main organizers of the volunteers transfer from Poland to the Carpathian Ruthenia was arrested.

Performing routine operations in the area of the Bohyński gorge, border guards from the I Line Branch in Polanica on December 6, 1938, at approx. 18.00 detained a group of 4 people, as it turned out later returning from the area of Carpathian Ruthenia. From the information obtained during the interrogation of detainees and also on the basis of an interview carried out by BG officers, it was determined that the detainees belonged to the group of nine residents of Delatyn, Zarzecze and Mikuliczyn, who on November 22, 1938 crossed the Polish border illegally to Czechoslovakia with the intention of joining the Carpathian Sich. This group was armed with a revolver and 2 rifles. During the interrogation detained, Iwan Weredziuk, son of Vasyl, born on 13.01.1918 in Mikuliczyn, a Ruthenian nationality, residing in Mikuliczyn, Nadworna area, testified during that:

at the beginning of October 1938, secretary of Proświta in Mikuliczyn, Bieljowicz Iwan together with other members of Proświta, Herkawy Jura from Stanisławów, (and) Piotr Prokopczuk from Tatarow, organized meetings in Proświta in Mikuliczyna conducting agitation and recruitment among the members of Proświta, that they would go to the Carpathian Ruthenia region and enter the Sich units. Bilejowicz Iwan has recruited 11 people and this is: 1 / Herkawy Jurko from Mikuliczyn who owned a pistol 2 / Fedorczuk / first name I do not know / from Dora also having a pistol, 4 / Kuśnierczuk Piotr from Jabłonica, Prokopczuk Piotr from Tatarow with a gun, 5 / Dracz Iwan from Worochta, two individuals "from" unknown to me from

association, and from November 9, 1938 - April 1939, he was a commander of the National Defense Organization Sicz Karpacka (Pahiria, 2010).

${ }^{22}$ Report on the interrogation of Jurko Sołowczuk detained during an attempt to illegally cross the border, drawn up on November 27, 1938 at the headquarters of the BG Office in Worochta, CDIA in Lviv, ref. No. 204/1/1244. 
Berezów from which Berezow I do not know with rifles and three unknown from the names from Zarzecze, next to Delatyn with one rifle, which group he led to the Carpathian Ruthenia above mentioned Bilejowicz.

In addition, during the hearing, Ivan Werdziuk informed the case leading commissioner, Bolesław Mościcki, that immediately after the illegal crossing of the border, on the Czechoslovak side, they were detained by the Czechoslovak police and imprisoned in the camp located in the town of Usteryki ${ }^{23}$.

During the interrogation of the next detainee Mikołaj Stefaniw, son of Semen, born on December 15, 1911, in Nieniwa Górna, in Dolina area, Ruthenian nationality, resident in Zarzecze, Nadwórna area, it was determined, among other things, that: on November 21, 1938, during a stay at the railway station in Delatyn, Mikołaj Stefaniw met with Włodzimierz Niszczej and Michał Klemiuk, residents of nearby villages, who persuaded him to go to the Czech Republic with them. During the interrogation, detained Mikołaj Stefaniw testified that

He said that instead of working in a sawmill in Mikuliczyn, I can enlist in the army in Ruthenia, where is very good, when I told him that I felt too old to the army, he told me that they are building for a new road in Ruthenia, at which they earn from 8 to 15 zloty a day and that later he will try to make me a policeman or border guard and I will be fine.

In the further part of the interrogation, Stefaniw Mikołaj describes his stay in Czechoslovakia, from which it appears that, after illegall crossing of Polish border to Czechoslovakia he was detained by Czechoslovak military police and placed in the Usteryki camp near Rachow

we were led to the military police where after some time and after joining of five other individuals from Poland, whose names I do not remember, they sent us all to Usteriki near Rachow, where we were all imprisoned in one place. One of the arrested was a professor placed in the same barrack. In Usteriki in the camp from November 24 to December 4 this year. we were working on chopping wood duties, some of us were carrying old narrow-gauge railway rails, and others were sweeping the yard. On November 24 Czechoslovak military police came to the barrack and asked in Czech language, who were we and why did we came. Everyone answered that we were Ukrainians and that we came to the army, to Sich.

During the interrogation, both detainees stated that the reason of their return to Poland were the poor living conditions in the Usteryki camp and the hard work to which they were forced by Czechoslovak military police. Due to the above factors, on December 5, 1938, they decided that they would escape together from the camp and return through the mountains to Poland. During the interrogation detainees informed that Włodzimierz Melnyk also escaped with them. The evidence collected in this case allowed to dismantle a group dealing

${ }^{23}$ Report of interrogation of Ivan Werdziuk detained during an attempt to illegally cross the state border, made on December 7, 1938 at the headquarters of the BG Worochta Office, CDIA in Lviv, ref. No. 204/1/1242. 
with the recruitment of volunteers to the Carpathian Sich operating in Mikuliczyn and the liquidation of the transfer channel of people in the area of the Bohyński gorge as well as to determine the role of individual members of this group in this practice. After the investigation, detainees were transferred to the Polish State Police.

Another person stopped by the Border Guard during an attempt to illegally cross the border on December 15, 1938 Stanisław Bezkorwany son of Anna, born on 11.11.1917 in Ternopol, living in Kudjance, Zbaraż area, testified during interrogation, among other things, that:

\begin{abstract}
...in Kudjańce I read Ukrainian newspapers "Nowy-Czas" and "Narodna -Sprawa" and I learned from newspapers that Ukraine was established in Carpathian Ruthenia, that Sich forms there, that there is a great demand for workers for the construction of roads and reconstruction of the city of Hust, which is the work done by German engineers, therefore I decided to go to Carpathian Ruthenia. I would also like to point out that the case of Carpathian Ukraine is widely commented in all villages by the Ukrainian people who gather together and tell eachother that after the new year, especially in spring, the great Ukraine with the lands of Małopolska area, part of Romania and Great Ukraine of Soviet Russia.
\end{abstract}

During the interrogation he informed the interviewing guard that

...to my host Mikolaj Podgórski in Kujdańce district. The neighbors came down in the evenings and talked about the future Ukraine, and especially the son of this host Oleksa, who goes to a cooperative in a place where Ukrainians come and talk about the future Ukraine... ${ }^{24}$.

The entire intelligence apparatus of the Border Guard was also involved in breakdown of the Ukrainian underground group operating in the border zone. Thanks to the confidential information provided by the informer, on October 20, 1938, the Border Guard patrol stopped two Polish citizens of the Ukrainian nationality, during an attempt of illegal crossing of the border with Czechoslovakia: Michał Korduba and Piotr Kulik. Detained Włodzimierz Korduba, born on December 7, 1917, son of Piotr, living in Lwów at 3 Gródecka Street, Ukrainian nationality, student of the Mathematics and Natural Sciences Department at the Jan Kazimierz University in Lviv, during the interrogation, which took place at the headquarters of the Worochta Office, gave a number of information which, among other things, indicated that

... he heard in Lviv that Subcarpathian Ruthenia receives its autonomy. Therefore, he decided to ascertain himself personally and (he) join the ranks of the Ukrainian police in the Subcarpathian Ruthenia, on 13 October 1938, he left Lviv to Worochta by train. He came to Worochta with his friend Kulik Piotr..." and also that "... in Jasin [in Czechoslovakia] there is no Ukrainian police, however, everything is in

\footnotetext{
${ }^{24}$ Report from the interrogation of Stanisław Bezkorwny, arrested during an attempt to illegally cross the state border, made on December 15, 1938 at the headquarters of the BG Worochta Station, CDIA in Lviv, ref. No. 204/1/1242.
} 
place, the military police and the Czech authorities continue to perform their duties.

As it was before ...

In addition, during the hearing, the above mentioned detainee gave information about the prevailing mood among the population in the Carpathian Ruthenia, which showed that "... the Ukrainian population supports separation from the Czech Republic and joining Hungary..." ${ }^{25}$. What's interesting, during the interrogation Włodzimierz Korduba concealed the fact, which was given by the BG informer that act of illegal crossing of the Polish border to Czechoslovakia he was helped by a resident of Woronienka, Dymitrij Onufrak, who showed him a convenient place to cross the Polish-Czechoslovak border ${ }^{26}$.

In this period there were also cases that the Czechoslovak military police turn over to the Polish side people who illegally entered Czechoslovakia. On November 16, 1938, the Czechoslovak side handed over to the Border Guard from the Ludwikówka Station ${ }^{27}, 15$ Polish citizens of Ukrainian nationality, who on November 14, 1938 illegally crossed the Polish-Czechoslovak border with the intention of joining the Carpathian Sich. Transfer on the aforementioned people from the Czech officer was accepted and in accordance with procedures they were arrested by the chef of local police Tadeusz Znojkiewicz and they were questioned about the illegal crossing of the state border. During the interrogation, Tadeusz Znojkiewicz obtained information about the way of recruitment of volunteers, their transfer across the border to Carpathian Ruthenia, as well as information about the Czech Border Guard reconnaissance of the Polish Border Guard. Interestingly, the Czechoslovak side, probably not having a thorough knowledge of the detainees, forwarded the Ukrainian courier, whose task was to reach the emerging Ukrainian autonomous authorities in Hust and provide information on the people moods in Poland.

During the interrogation of the illegal crossing, which took place on November 16, 1938 at the headquarters of theBG Ludwikówka office, Paweł Horoszyn, son of Dmytr, born on January 25, 1914 in Oslowce Czarne, Nadworna area, living in Osławy Czarne, testified, among other things, that

... after crossing the borders we came to the cloister, where we were stopped by the Czech guards and escorted to Jasina [the in Czechoslovakia]. Here, (they) carried out a personal search and investigation. On 11.XX this year. by train they took us to Hust, where a re-investigation was conducted, during which I was asked if there was a Border Guard station in Polanica, how many guards there were. Which I replied that the Border Guard is, however how many guards I do not know. After the interrogation, we were place in custody, where we found 4 individuals who also crossed the border between Poland and the Czech Republic illegally ..." and that "....

${ }^{25}$ Report from the interrogation of Włodzimierz Korduba detained during illegal crossing of the state border from Czechoslovakia to Poland which took place on October 20, 1938 at the headquarters of the Worochta Station, CDIA in Lviv, reference number 204/1/1242.

${ }^{26}$ As Above.

${ }^{27}$ Ludwikówka Station - the territorial unit of the Border Guard was directly subordinate to the Border Guard Inspectorate in Stryj. BG Ludwikówka Station was responsible for the protection of the state border of $31.51 \mathrm{~km}$ in the Carpathian region. The border guards area of the Ludwikówka Station was the border area of the Dolina area. Border guard tasks were carried out by guards from the First Line Branch in Seneczów, Beskid Klauza and in Wyszków, as well as from the 2nd Line Branch in Ludwikówka (Kozłowski, 2015). 
While abroad, I did not receive any information, except that I saw a lot of Czech soldiers in the Hust. What were the regiments, that I do not know... ${ }^{28}$

Obtained information about the interest of the Czechoslovak Border Guards in the Polish Border Guard was also confirmed during the interrogation of the next detained Polish citizen of Ukrainian nationality Bogdan Horyszyna, son of Aleksander, born July 4, 1912 in Ostaway Czarne.

Another person handed in by the Czechoslovak side and detained was Polish citizen of the Ukrainian nationality Ołeksy Kret son of Grzegorz, born on September 4, 1921 in Peczenia, Przemyślany area, a member of the OUN, who in October 1938 performed a courier mission between the local structure of the OUN in Poland and the Ukrainian Government in Carpathia. During the hearing of the abovementioned, he testified, among other things, that:

I did not receive any financial help for the way, because Stefan Petryczka, who sent me to Carpathia, told me that I will need my own money, because the organization have no money. The above-mentioned ordered me to take a map from Ilka Hupała who lived in Peczenia, before going abroad. Stefan Petryczka, who lived in Peczenia as the leader of the OUN's duel, told me to avoid the police stations before going abroad. On November 14th this year when I was returning from the field near the house of Petryczka, he called me to the courtyard and gave me instructions to go to Carpathia together with Paciórko Jan ... "and also that" ... Paciórko Jan is to join the Ukrainian Legion, and I was supposed to reach Rewaj ${ }^{29}$ who lived in Hust, to whom I had to say that there is a lot of organized Ukrainian youth in Poland who absolutely wants to go to help in the liberation of Ukraine in Carpathia, and at the same time I was to ask whether Ukrainian youth is needed in that government. Then I had a order from Petryczka Stefan to bring in a command and a letter of the unknown content that Rewaj or his deputy was to give me...

The sent courier from Poland was informed about the address to which he was supposed to go in Carpathian Ruthenia, as well as about the current identification slogan:

... While giving me the above command Petryczka Stefan, said that after crossing the border to Czechoslovakia I had to report to the nearest Ukrainian military police post and give the password »Ukraine« to which the answer was to be »Chej Żywe (Alive)«. In the event of any misunderstandings, I had to ask them to report to Rewaj in Hust by phone that two boys from Poland from the OUN party, have come to give them some information...

${ }^{28}$ Report from the interrogation of Paweł Horoszyn, arrested during an attempt to illegal crossing of the state border, made on November 16, 1938 at the headquarters of the BG Station in Ludwikówka, CDIA in Lviv, ref. No. 204/1/1245.

${ }^{29}$ Probably it was about Julian Rewaj (1899-1979), teacher, politician of the Czechoslovak parliamentary delegate in 1935-1938, in September 1938 minister of trade, transport and work in the autonomous government of Carpathian Ukraine, co-author of the Czechoslovak Act on granting the autonomous status for the Carpathian Ruthenia , the last Prime Minister of the Carpathian Ukraine government (Pahiria, 2010). 
Besides, in the further part of the interrogation, detained Oleksy Kret described the method of recruiting volunteers from Poland to Carpathian Ruthenia conducted among Ukrainian youth and the role which Stanisław Petryczka played in this process:

... exactly three weeks ago a meeting of members of the OUN took place in the Petryczka house, where Małakowski Józef arrived from Przemyślan, and asked to somehow drag the Ukrainian youth to the OUN because the Subcarpathian Ruthenia, which had autonomy, has a Ukrainian government and creates a Ukrainian legion to which, if necessary, we will gradually send Ukrainian youth and the rest will stay in place and when there will be a need they will defence the Ukrainian nation...

Later in the hearing of the aforementioned detainee, he testified to the interviewer that during the reading Małakowski stated that when the Ukrainians from Carpathian Ruthenia together with the Germans will move to attack USSR "...the Ukrainians will purge Eastern Poland..." and that after the reading Małakowski instructed Petryczka to take the oath of loyalty to the Ukrainian people from 16 newly recruited members of the OUN. The testimony report also shows that the above mentioned meeting was attended by the management of the OUN from Przemyślany region, which was then: Piotr Szewciów, deputy district manager in charge, Ryszniak Michał - financial manager, Hrynko ... battle manager, Czyńko Paweł - propaganda manager and Prokop Wasyl - recruitment manager ${ }^{30}$.

During they standard operation duties of border patrol Border Guards also detained young men attempting to illegally cross the border into Czechoslovakia, whose main motive was to look for work in the Carpathian Ruthenia. Those people, remaining without constant work in Poland or doing low-paid jobs, submitted to Ukrainian propaganda, which claimed that the emerging Ukrainian state in Carpathian Ruthenia needs young people to work on road investments. This information also appeared in the Ukrainian illegal press published at that time.

On November 28, 1938, during an interrogation, which took place in the BG Worochta station, detained Polish citizen of Ukrainian nationality Jura Odokij son of Fedor, born in June 6, 1914 in the village of Hawryłowka, Nadworna area, testified

... that after leaving the state sawmill in Mikuliczyn I was approached by, a worker Slowoczuk Jurko, who called me on the side and attemted to persuade me to go with him to the Carpathian Ruthenia, as there is work on building roads or I could join the Ukrainian army, where they pay well and give clothing. Having heard of the good existence conditions in Ruthenia, I was persuaded and went along with Solowczuk Jura on November 26, 1938 to the Carpathian Ruthenia.

Additionally, detainee testified that "....after crossing the border we had to go to Jasin and report to Klempusz, who would send us to work or to the Ukrainian Sich units in Carpathian Ruthenia..." 31 .

${ }^{30}$ Protocol from the interrogation of Oleks Kreta, given to the Polish side by the Czechoslovak gendarmerie, which took place on October 28, 1938 at the headquarters of the Ludwikówka Station, CDIA in Lviv, ref. No. 204/1/1245.

${ }^{31}$ Report from the interrogation of Jura Odokija detained during an attempt to illegally cross the Polish border to Czechoslovakia, which took place on November 28, 1938 at the headquarters of the BG Worochta station, CDIA in Lviv, ref. act 204/11243. 
Next detained on December 12, 1938 during an attempt to illegal crossing of the Polish border to Czechoslovakia on the section subordinate to the BG station in Ławoczne, was a Polish citizen of Ukrainian nationality Michał Nosar, son of Stefan, born in 1901 in Wyzlow. During the interrogation, he testified, among other things:

... in Proswita in the town of Wyżłów, I read in the newspaper »Prapor « and »Nowy Czas « that now there are new roads being built in the Carpathian Ruthenia, where 30,000 workers were hired, and another 20,000 will receive job... ${ }^{32}$.

Another detained Polish citizen of Ukrainian nationality Jan Koropaś, son of Teodor, born on January 3, 1913 in Rożubowice, Przemyśl area, a Proświta member in Rożubowice - handed over by the Czechoslovak border guard for crossing the Polish border illegally to Czechoslovakia. As the explanation of his decision to illegally enter the Carpathian Ruthenia, he gave the will to find job in Hust. During the interrogation, he stated, that

... Not having an appropriate documents to conduct work in the workshop in October this year, the State Police station in Siedliska, categorically forbade me to conduct a carpentry work in workshop, as an evidence of which the workshop building was sealed. Being unemployed, I read the newspapers Nowy Czas i Nasz Prapor in which I read that in the Carpathian Ruthenia region, the expansion of the capital of Carpathian Ruthenia and the city of Hust and work on construction of iron and wheeled roads are in high demand of workers for the above mentioned works. Based on the news from the press, I decided to illegally cross the border from Poland to Czechoslovakia to get a job in Carpathian area... ${ }^{33}$

In the aforementioned cases, the lack of work and adequate salary paid for the completed work as well as the generally poverty, especially in the countryside, was one of the reasons for the intention of illegal crossing of the state border in search of job in the Carpathian Ruthenia.

To summarise the above, it should be stated that the mass inflow of Ukrainian youth to the Polish border region that took place at the end of 1938 and the attempts to illegal crossing of the state border influenced the number of people detained by the border services. At the same time, the level of internal security of the Polish state, especially on the borderland in the Carpathian region, has also decreased dramatically. From the quoted intelligence material, it appears that each border service, both the Polish Border Guard and Finančna Stráž Československá used every opportunity to conduct border and military intelligence investigations. One of these opportunities was undoubtedly the possibility of taking intelligence information during interrogation of people detained for illegal border crossing or for staying in the border zone without the required permit. The Border Guard, cooperating with Officers' Stations of the Independent Information Departments, aim to uncover the Ukrainian

\footnotetext{
${ }^{32}$ Report from the interrogation of Michał Nosar detained during an attempt to illegally cross the Polish border to Czechoslovakia, which took place on December 12, 1938 at the headquarters of BG station in Ławoczny, CDIA in Lviv, ref. No. 204/11243.

${ }^{33}$ Report from the interrogation of Jan Koropas, detained on December 2, 1938 at the headquarters of VG station in Ludwikówka, after being handed over by the Czechoslovak side for illegally crossing the Polish border to Czechoslovakia, CDIA in Lviv, ref. act 204/11245.
} 
underground in Poland and its connections with the government of Carpathian Ukraine, in which largely succeeded. A detailed analysis of the protocols of people detained by BG as well as those turned in by the Czechoslovak Border Services presents a grim picture of the reality prevailing at that time. The protocols of the interrogation shows that the unresolved socio-economic and political problems of the Second Polish Republic were the cause of radicalization of Ukrainian attitudes in Poland. The contents of the explanations submitted to the detention reports clearly shows that in many cases the reason for the "emigration" of Ukrainian youth in Carpathian Ruthenia was the lack of jobs in Poland and the hazy prospect of receiving it in the Carpoathian Ruthenia, and subsequently willingness to serve in the Ukrainian armed forces of the Carpathian Sich. This situation was perfectly used by the OUN management in Poland. Lack of perspective for Ukrainian youth, especially in the border region was a flywheel driving volunteers to the OUN as well as to the defence units of the Carpathian Sich, where Polish volunteers would get food, uniforms and pay. The recruitment campaign was conducted by Greek Catholic priests and the OUN management during meetings that usually took place in the Proświta reading clubs ${ }^{34}$. During the recruitment, they promised to the willing positions in the forming Ukrainian state administration and the police units in the Carpathian Ukraine, as well as work on the planned road works. It was pure demagogy, because in the interwar period the area of the Subcarpathian Ruthenia deprived of industry was one of the poorest regions in Czechoslovakia and just such jobs for hundreds of people willing from Poland could not be provided there. The next issue, which appears in the report on the interrogation of Oleks Kret, is the announcement of future ethnic cleansing that took place during the Second World War in the area of Eastern Małopolska and Wołyń - and in consequence, the slaughter of thousands of Poles by the Ukrainian Insurgent Army.

Today, based on the preserved archival materials from the area of the BG Station Worochta and in Ludwikówka, it is extremely difficult to assess how the intelligence material obtained during the interrogations of people detained, directly influenced the security level in the eastern territories of the Second Polish Republic.

Nevertheless, one should assume that the information obtained by the Małopolska BG was largely obtained by recognizing the Ukrainian underground operating in the border area. Which in leading a large scale of recruitment of new members and transferring them across the border, felt so confident that it ceased to hide and obey the rules of conspiracy as evidenced by the quoted fragments of interrogation of detainees. As a result of the reconnaissance carried out by the Polish border service (BG and BPC), the Ukrainian activists were arrested in Poland by the State Police and the Polish citizenship of the Polish volunteers serving in the Carpathian Sich was withdraw.

As a certification of the scale of the intelligence activities carried out by the Małopolska Border Guard and the quality of obtained intelligence information in the field of recognition of the Ukrainian movement is the fact that after the eastern Poland was occupied by the USSR, the Soviet authorities were unable to cope with the Ukrainian underground in

\footnotetext{
${ }^{34}$ Situational report of the Headquarters of the Eastern-Małopolska Border Guards District in Lviv No. 11/38 of December 15, 1939 (Act of the Małopolska Provincial District Inspectorate, CDIA in Lviv, ref. No. 204/1/1166).
} 
Western Ukraine in 1945 the year and had to reach for the pre-war materials of the Border Guard $^{35}$.

\section{REFERENCES}

Beneš J. (2005). Finančni Stráž Československá 1918-1938. Mlada Boleslaw.

Dąbrowski D. (2007), Rzeczpospolita Polska wobec kwestii Rusi Zakarpackiej (Podkarpackiej) 1938-1939. Toruń.

Kozłowski P. (2015). Forgotten advocates of south-eastern borders of the Second Polish Republic 1922-1939. Biographical Dictionary of officers, guards and employees of the Customs Guard and Border Guard, Przemyśl.

Kulińska L. (2009). Terrorist and sabotage activities of Ukrainian nationalist organizations in Poland in the years 1922-1939. Kraków

Pahiria O. (2010). Каппітська Січ військове формування Карпатської Украӥни. Kiev.

Wielka ilustrowana encyklopedia powszechna by Gutenberg Publishing House (1932), Kraków. Wiśniewski J.P. (2007). Armia czechosłowacka w latach 1932-1938. Toruń.

\section{Attachment \# 1}

List of Polish citizens of Ukrainian nationality detained in the area of the Eastern-Małopolska District, who during the interrogation proved that they attempted to illegally enter the area of Carpathian Ruthenia with the intention of joining the Carpathian Sich:

\begin{tabular}{|r|l|l|l|l|}
\hline & \multicolumn{1}{|c|}{ Surname and First Name } & \multicolumn{1}{c|}{ Date of birth } & Place of residence & Area of residence \\
\hline 1 & Sirecki Eugeniusz & 21.04 .1921 & Opaka & Drohobycz \\
\hline 2 & Kiszczak Jan & 9.03 .1919 & Żołdec & Źółkiew \\
\hline 3 & Szmorhaj Semen & & Korczyn & Sokal \\
\hline 4 & Pociorko Jan & & Peczenie & Przemyślany \\
\hline 5 & Kret Ołeksy & 4.09 .1921 & Peczenie & Przemyślany \\
\hline 6 & Sowiak Wasyl & 4.01 .1915 & Lisznia & Drohobycz \\
\hline 7 & Prokopiw Bohdan & & Duliby & Bórbka \\
\hline 8 & Lewickij Mokołaj & & Mołodyniec & Bóbrka \\
\hline 9 & Homusiak Antoni & & Mołodyniec & Bóbrka \\
\hline 10 & Soroczak Leon & & Perehińsko & Dolina \\
\hline 11 & Łesiuk Jakiw & & Rafajłowa & Nadwórna \\
\hline 12 & Dideńko Jan & & Perechińsko & Dolina \\
\hline 13 & Patryj Włodzimierz & & Perecheńsko & Dolina \\
\hline 14 & Hłuszko Piotr & & Perehińsko & Dolina \\
\hline
\end{tabular}

35 There is a note in the Lviv archives files, containing protocols from interrogation of detainees during attempts to illegally cross the border in files of Ivan Dymiterki [which are incomplete], (documents taken over and removed from the collection of the pre-war BG document by the NKVD) prepared by the NKVD Board Member of the State Security Service Sergeant Kurianov testifying of the penetration of intelligence material by Soviet special services. CDIA in Lviv (Act team of the Małopolska Provincial District Inspectorate, reference number No. 204/1/1244, p. 162). 


\begin{tabular}{|l|l|l|l|l|}
\hline & \multicolumn{1}{|c|}{ Surname and First Name } & Date of birth & Place of residence & Area of residence \\
\hline 15 & Zakliński Świętosław & & Monasterzyska & Buczacz \\
\hline 16 & Kowalik Iwan & & Kuty & Kosów \\
\hline 17 & Krawczuk Marian & & Perehańsko & Dolina \\
\hline 18 & Śliwiński Wasyl & & Podniszczany & Bóbrka \\
\hline 19 & Horyszyn Bogdan & 4.07 .1912 & Tatarów & Nadwórna \\
\hline 20 & Horyszyn Paweł & 16.11 .1938 & Ostawy Czarna & Nadwórna \\
\hline 21 & Jaremczuk Piotr & & Rafajłowa & Nadwórna \\
\hline 22 & Dymczyszyn Dionizy & & Kołomyja & Kołomyja \\
\hline 23 & Sołowij Piotr & 21.04 .1924 & Mikuliczyn & Nadwórna \\
\hline 24 & Sołowczuk Jurko & 11.03 .1914 & Mikuliczyn & Nadwórna \\
\hline 25 & Odokij Jurko & 6.06 .1914 & Mikuliczyn & Nadwórna \\
\hline 26 & Staruszkiewicz Wasyl & & Rozłucz & Turka n/ Stryjem \\
\hline 27 & Sachajdak Włodzimierz & 8.01 .1912 & Kopyczyńce & \\
\hline 28 & Kordybaniuk Bohdan & 11.05 .1920 & Słobódka Leśna & Kołomyja \\
\hline 29 & Drmohraj Wasyl & & Lwów & \\
\hline 30 & Słucki Michał & & Schodnica & Drochobycz \\
\hline 31 & Kaczmar Stefan & & Przemyśl & Przemyśl \\
\hline 32 & Swyszcz Aleksander & & Kropiwnik Nowy & Drohobycz \\
\hline 33 & Dziubak Józef & & Schodnica & Dohobycz \\
\hline
\end{tabular}

Source: Author's own work based on the Situation Report of the Eastern-Malopolska Border Guards District in Lviv No. 11/38 of December 15, 1939.

DOI: $10.7862 /$ rz.2019.hss.16

The text was submitted to the editorial office: December 2018.

The text was accepted for publication: June 2019. 